\title{
Proposal of Bacillus reuszeri sp. nov., Bacillus formosus sp. nov., nom. rev., and Bacillus borstelensis sp. nov., nom. rev. OSAMU SHIDA, ${ }^{1 *}$ HIROAKI TAKAGI,${ }^{1}$ KIYOSHI KADOWAKI, ${ }^{1}$ SHIGEZO UDAKA, ${ }^{2}$ LAWRENCE K. NAKAMURA, ${ }^{3}$ AND KAZUO KOMAGATA ${ }^{4}$
}

Research Laboratory, Higeta Shoyu Co., Ltd., Choshi, Chiba $288,{ }^{1}$ and Department of Brewing and Fermentation ${ }^{2}$ and Department of Agricultural Chemistry, ${ }^{4}$ Faculty of Agriculture, Tokyo University of Agriculture, Setagaya-ku, Tokyo 156, Japan; and Microbial Properties Research, National Center for Agricultural Utilization Research, Agricultural Research Service, U.S. Department of Agriculture, Peoria, Illinois $61604^{3}$

Taxonomic studies of 26 putative Bacillus brevis strains (12 strains formerly assigned to groups 2,4 through 7 , and $B$ and 14 ungrouped strains) were carried out. These organisms were placed in five distinct groups on the basis of phenotypic characteristics, the results of DNA base composition and reassociation analyses, and the results of cellular fatty acid and isoprenoid quinone composition analyses. Group 2, which contained three strains, was identified as Bacillus choshinensis, and group 4, which contained one strain, was identified as Bacillus parabrevis. The three remaining unidentified groups were clearly distinguishable phenotypically and genetically from the type strains of $B$. brevis and the recently described species Bacillus agri, Bacillus centrosporus, Bacillus migulanus, Bacillus choshinensis, and Bacillus parabrevis. Therefore, the names Bacillus reuszeri sp. nov., Bacillus formosus sp. nov., nom. rev., and Bacillus borstelensis sp. nov., nom. rev. are proposed for groups 5 (3 strains), 6 (3 strains), and 7 (16 strains), respectively. The S-layer proteins found in the three new species were immunologically and genetically similar to the $S$-layer proteins found previously in $B$. brevis, $B$. agri, B. centrosporus, $B$. choshinensis, and $B$. parabrevis. The G+C content of NRRL NRS-1206, the type strain of $B$. reuszeri sp. nov., was $46.5 \mathrm{~mol} \%$; the G+C content of NRRL NRS-863, the type strain of $B$. formosus sp. nov., nom. rev., was $47.2 \mathrm{~mol} \%$; and the G+C content of NRRL NRS-818, the type strain of $B$. borstelensis sp. nov., nom. rev., was 51.3 mol\%.

Previously, Nakamura $(6,7)$ and Takagi et al. (11) independently studied the taxonomy of Bacillus brevis and, on the basis of phenotypic, chemosystematic, and DNA relatedness data, separated the organisms in this species into seven species $(B$. brevis sensu stricto, Bacillus agri, Bacillus centrosporus, Bacillus migulanus, Bacillus choshinensis, Bacillus parabrevis, and Bacillus galactophilus) and six unidentified groups. Recently, Shida et al. (8) studied the six species described by Nakamura (7) and Takagi et al. (11) and established that $B$. galactophilus is a later subjective synonym of $B$. agri. The taxonomic status of the five unidentified groups of Nakamura (7) (groups 2 and 4 through 7) and one strain belonging to group B of Takagi et al. (11) was not resolved by these authors. We performed this study to establish the taxonomic positions of these organisms, as well as 14 other $B$. brevis-like strains; to do this, we examined the phenotypic characteristics of these bacteria, as well as chemosystematic data, DNA base compositions, and levels of DNA relatedness.

\section{MATERIALS AND METHODS}

Bacterial strains. The bacterial strains used in this study are listed in Table 1 Working stocks were cultured on T2 agar plates (12) for $24 \mathrm{~h}$ at $30^{\circ} \mathrm{C}$ and were stored at room temperature.

Phenotypic characterization. Phenotypic characteristics of 22 strains (strains 5 through 26 in Table 1) were determined as described previously $(6,7,11)$.

DNA base composition and DNA relatedness. The procedures used to isolate and purify chromosomal DNA and to estimate DNA base composition have been described previously (11). The $\mathrm{G}+\mathrm{C}$ contents of 26 strains (strains 1 through 26 in Table 1) were determined. DNA relatedness values were determined by using probes labeled with photobiotin (Vector Laboratories, Inc., Burlingame, Calif.) in microplate wells and the fluorometric method described by Ezaki et al. (2). Probes for DNA-DNA hybridization experiments were prepared from B. brevis

* Corresponding author. Mailing address: Research Laboratory, Higeta Shoyu Co., Ltd., 2-8 Chuo-cho, Choshi, Chiba 288, Japan. Phone: 81-479-22-1180. Fax: 81-479-24-3422.
JCM $2503^{\mathrm{T}}$ ( $\mathrm{T}=$ type strain), B. agri NRRL NRS- $1219^{\mathrm{T}}$, B. centrosporus NRRL NRS-664 ${ }^{\mathrm{T}}$, B. migulanus ATCC $9999^{\mathrm{T}}, B$. choshinensis HPD52 ${ }^{\mathrm{T}}$, B. parabrevis IFO $12334^{\mathrm{T}}$, and the following Bacillus sp. strains: NRRL NRS-1206 ${ }^{\mathrm{T}}$, NRRL NRS-1208, NRRL NRS-863' ${ }^{\mathrm{T}}$, NRRL NRS-1210, NRRL NRS-818 ${ }^{\mathrm{T}}$, NRRL NRS-1029b, NRRL NRS-948, and HP926.

Cellular fatty acid and isoprenoid quinone compositions. Cells were cultured as described previously (11). Cellular fatty acids and isoprenoid quinones were prepared and cellular fatty acid and isoprenoid quinone compositions were determined as described by Komagata and Suzuki (3).

Immunological analysis. The procedures used for electrophoretic analysis and Western blot (immunoblot) analysis of whole-cell proteins have been described previously $(8,9,11)$. Rabbit antiserum against the S-layer protein (protein HWP) of $B$. choshinensis HPD31 was prepared as described elsewhere $(1,11)$.

Southern blot analysis. Chromosomal DNAs were digested completely with $E c o$ RI, and then the digested DNAs were separated by electrophoresis on $0.8 \%$ agarose gels. A Southern blot analysis of chromosomal DNA restriction fragments was performed as described by Takagi et al. (11). The hybridization probe used was a $1.0-\mathrm{kb} H p a I-B g l I I$ fragment of $\phi-S K 10$ containing the HWP gene of $B$. choshinensis HPD31 $(1,11)$. Hybridization of the probe to the digested DNA was detected with an enhanced chemiluminescence gene detection system (Amersham International plc, Amersham, United Kingdom) by using the manufacturer's protocol.

\section{RESULTS}

DNA base composition and DNA relatedness. The DNA base compositions ( $\mathrm{G}+\mathrm{C}$ contents) of the 26 strains studied ranged from 46.4 to $51.8 \mathrm{~mol} \%$ (Table 2 ).

Table 2 shows that the levels of DNA relatedness between $B$. choshinensis HPD52 ${ }^{\mathrm{T}}$ and group 2 strains NRRL NRS-376, NRRL NRS-378, and NRRL NRS-380 and between $B$. parabrevis IFO $12334^{\mathrm{T}}$ and representative group 4 strain NRRL NRS-815 were greater than $70 \%$. Furthermore, we observed low levels of DNA reassociation between the type strains of the species tested and members of $B$. brevis-like groups 5 through 7 and $B$ and 14 ungrouped strains (strains 10 and 14 through 26 in Table 1).

Table 3 shows levels of DNA relatedness between previously unclassified $B$. brevis sensu lato strains. Intragroup levels of 
TABLE 1. Bacterial strains used in this study

\begin{tabular}{|c|c|c|c|}
\hline \multicolumn{2}{|r|}{ Strain } & \multirow{2}{*}{ Source $^{a}$} & \multirow{2}{*}{ History ${ }^{b}$} \\
\hline Laboratory no. & Designation & & \\
\hline \multicolumn{4}{|l|}{ Group 2 strains $^{c}$} \\
\hline 1 & NRRL NRS-376 & 1 & N. R. Smith, from soil \\
\hline 2 & NRRL NRS-378 & 1 & N. R. Smith, from soil \\
\hline 3 & NRRL NRS-380 & 1 & N. R. Smith, from soil \\
\hline \multicolumn{4}{|l|}{ Group 4 strain $^{c}$} \\
\hline & NRRL NRS-815 & 1 & J. R. Porter, "Bacillus bellus" B1, from G. Bredemann \\
\hline \multicolumn{4}{|l|}{ Group 5 strains $^{c}$} \\
\hline 5 & NRRL NRS-1206 & 1 & H. W. Reuszer Army strain $39^{\mathrm{T}}\left(=\mathrm{JCM} 9170^{\mathrm{T}}=\mathrm{IFO} 15719^{\mathrm{T}}\right)$ \\
\hline 6 & NRRL NRS-1207 & 1 & H. W. Reuszer Army strain 723 \\
\hline 7 & NRRL NRS-1208 & 1 & H. W. Reuszer Army strain 842 \\
\hline \multicolumn{4}{|l|}{ Group 6 strains ${ }^{c}$} \\
\hline 8 & NRRL NRS-863 ${ }^{\mathrm{T}}$ & 1 & $\begin{array}{l}\text { J. R. Porter, "Bacillus formosus" F12 } 2^{\mathrm{T}} \text {, from G. Bredemann } \\
\left(=\text { JCM } 9169^{\mathrm{T}}=\text { IFO } 15716^{\mathrm{T}}\right)\end{array}$ \\
\hline 9 & NRRL NRS-1210 & 1 & H. W. Reuszer Army strain 1035 \\
\hline \multicolumn{4}{|r|}{ (1) } \\
\hline 11 & NRRL NRS-818 & 1 & J. R. Porter, "Bacillus borstelensis" (= JCM $9022^{\mathrm{T}}=$ IFO $\left.15714^{\mathrm{T}}\right)$ \\
\hline 12 & NRRL NRS-1029b & 1 & G. M. Eisenberg, "Bacillus schuylkilliensis" \\
\hline \multicolumn{4}{|l|}{ Group B strain ${ }^{d}$} \\
\hline 13 & HP926 & 2 & H. Takagi et al., from soil \\
\hline \multicolumn{4}{|l|}{ Ungrouped strains } \\
\hline 10 & NRRL NRS-910 & 1 & $\begin{array}{l}\text { J. R. Porter, "Bacillus mycoides" M26, from G. Bredemann from } \\
\text { O. Gottheil }\end{array}$ \\
\hline 14 & NRRL NRS-948 & 1 & J. R. Porter, "Bacillus rufescens" R8, from G. Bredemann \\
\hline 15 & NRRL NRS-1373 & 1 & W. G. Walter strain 141 , from a hot spring \\
\hline 16 & CCM 1613 & 3 & H. Proom (= DSM $298=$ CN 2918) \\
\hline 17 & NCFB 1133 & 4 & Wellcome collection, through J. G. Franklin, NIRD 1957 (= CN 2904) \\
\hline 18 & NCFB 1158 & 4 & Wellcome collection, through J. G. Franklin, NIRD 1957 (= CN 3010) \\
\hline 19 & NCFB 1165 & 4 & Wellcome collection, through J. G. Franklin, NIRD 1957 (= CN 3005) \\
\hline 20 & S038 & 5 & NCIB 8803 \\
\hline 21 & S042 & 5 & WR 2904, from soil \\
\hline 22 & S043 & 5 & No information available \\
\hline 23 & S044 & 5 & WR 2932, from soil \\
\hline 24 & S047 & 5 & WR 3005 , from soil \\
\hline 25 & E15 & 6 & No information available \\
\hline 26 & E16 & 6 & No information available \\
\hline \multicolumn{4}{|r|}{ 然 } \\
\hline 27 & B. brevis JCM $2503^{\mathrm{T}}$ & 7 & $\begin{array}{l}\text { DSM } 30^{\mathrm{T}} \text { from ATCC } 8246^{\mathrm{T}} \text { from N. R. Smith strain } 604^{\mathrm{T}} \text { from } \\
\text { J. R. Porter from NCTC } 2611^{\mathrm{T}} \text { from W. W. Ford strain } 27 \mathrm{~B}^{\mathrm{T}}\end{array}$ \\
\hline 28 & B. agri NRRL NRS- $1219^{\mathrm{T}}$ & 1 & N. R. Smith strain $1219^{\mathrm{T}}$ from C. Lamanna strain $13^{\mathrm{T}}$ \\
\hline 29 & B. centrosporus NRRL NRS- $664^{\mathrm{T}}$ & 1 & N. R. Smith strain $664^{\mathrm{T}}$ from B. S. Henry strain $120^{\mathrm{T}}$ \\
\hline 30 & B. migulanus ATCC $9999^{\mathrm{T}}$ & 8 & $\begin{array}{l}\text { NCTC } 7096^{\mathrm{T}} \text { from R. Synge from Moscow, gramicidin S-producing } \\
\text { strain }\left(=\text { JCM } 8504^{\mathrm{T}}=\text { IFO } 15520^{\mathrm{T}}=\text { CIP } 103841^{\mathrm{T}}\right)\end{array}$ \\
\hline 31 & B. choshinensis HPD52 ${ }^{\mathrm{T}}$ & 2 & $\begin{array}{l}\text { H. Takagi et al., from soil, protein-producing strain }\left(=\mathrm{JCM} 8505^{\mathrm{T}}=\right. \\
\left.\text { IFO } 15518^{\mathrm{T}}=\text { CIP } 103838^{\mathrm{T}}=\text { DSM } 8552^{\mathrm{T}}\right)\end{array}$ \\
\hline 32 & B. choshinensis HPD31 & 2 & H. Takagi et al., from soil, protein-producing strain \\
\hline 33 & B. parabrevis IFO $12334^{\mathrm{T}}$ & 9 & $\begin{array}{l}\text { ATCC } 10027^{\mathrm{T}} \text { from N. R. Smith strain } 605^{\mathrm{T}} \text { from J. R. Porter from } \\
\text { G. Bredemann }\left(=\mathrm{JCM} 8506^{\mathrm{T}}=\text { CIP } 103840^{\mathrm{T}}\right)\end{array}$ \\
\hline
\end{tabular}

${ }^{a}$ 1, NRRL, Agricultural Research Service Culture Collection, National Center for Agricultural Utilization Research, Peoria, Ill.; 2, Research Laboratory, Higeta Shoyu Co., Ltd., Chiba, Japan; 3, CCM, Czech Collection of Microorganisms, Masaryk University, Brno, Czech Republic; 4, NCFB, National Collection of Food Bacteria, Shinfield, Reading, United Kingdom; 5, Heriot-Watt University, Edinburgh, Scotland, United Kingdom; 6, Yamaguchi University School of Medicine, Yamaguchi, Japan; 7, JCM, Japan Collection of Microorganisms, Saitama, Japan; 8, ATCC, American Type Culture Collection, Rockville, Md.; 9, IFO, Institute for Fermentation, Osaka, Japan.

${ }^{b}$ Names in quotation marks are not on the Approved Lists of Bacterial Names (10) or the Index of the Bacterial and Yeast Nomenclatural Changes (5) and have not been validly published since 1 July 1994. NIRD, National Institute for Research in Dairying, Shinfield, Reading, United Kingdom; DSM, Deutsche Sammlung von Mikroorganismen und Zellkulturen GmbH, Braunschweig, Germany; CN, Burroughs Welicome Research Laboratories, Kew, Surrey, United Kingdom; NCIB, National Collection of Industrial and Marine Bacteria, Ltd., Aberdeen, Scotland, United Kingdom; WR, Queensland Wheat Research Institute, Toowoomba, Australia; NCTC, National Collection of Type Cultures, Central Public Health Laboratory Service, London, United Kingdom; CIP, Collection des Bactéries de l'Institut Pasteur, Paris, France; JCM, Japan Collection of Microorganisms, Saitama, Japan; IFO, Institute for Fermentation, Osaka, Japan; ATCC, American Type Culture Collection, Rockville, Md.

${ }^{c}$ Group designation used by Nakamura (7).

${ }^{d}$ Group designation used by Takagi et al. (11).

DNA relatedness higher than $71 \%$ and intergroup levels of relatedness lower than $26 \%$ indicated that Nakamura groups 5 through 7 were genetically distinct groups. Moreover, the DNA relatedness study revealed that HP926, a strain previously assigned to group B of Takagi et al. (11), and all 13 ungrouped strains (strains 14 through 26 in Table 1) were closely related genetically to the group 7 organisms. In his 1991 study (6), Nakamura showed that NRRL NRS-910 (strain 10 in Table 1) was not a $B$. brevis sensu stricto strain, but this strain was not included in his subsequent study (7). High levels of 
TABLE 2. DNA base compositions and levels of DNA relatedness for B. brevis sensu stricto, B. agri, B. centrosporus, B. migulanus, $B$. choshinensis, and $B$. parabrevis strains and previously ungrouped $B$. brevis-like organisms

\begin{tabular}{|c|c|c|c|c|c|c|c|c|}
\hline \multicolumn{2}{|r|}{ Strain } & \multirow{2}{*}{$\begin{array}{c}\mathrm{G}+\mathrm{C} \\
\text { content } \\
(\mathrm{mol} \%)\end{array}$} & \multicolumn{6}{|c|}{$\%$ Reassociation with DNA from ${ }^{a}$ : } \\
\hline $\begin{array}{c}\text { Laboratory } \\
\text { no. }\end{array}$ & Designation & & $\begin{array}{l}\text { B. brevis } \\
\mathrm{JCM} 2503^{\mathrm{T}}\end{array}$ & $\begin{array}{l}\text { B. agri NRRL } \\
\text { NRS- } 1219^{\mathrm{T}}\end{array}$ & $\begin{array}{l}\text { B. centrosporus } \\
\text { NRRL NRS- } 664^{\mathrm{T}}\end{array}$ & $\begin{array}{l}\text { B. migulanus } \\
\text { ATCC } 9999^{\mathrm{T}}\end{array}$ & 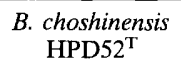 & $\begin{array}{l}\text { B. parabrevis } \\
\text { IFO } 12334^{\mathrm{T}}\end{array}$ \\
\hline 1 & NRRL NRS-376 & 47.9 & 28 & 12 & 25 & 7 & 80 & 20 \\
\hline 2 & NRRL NRS-378 & 48.1 & 21 & 12 & 23 & 6 & 88 & 14 \\
\hline 3 & NRRL NRS-380 & 48.3 & 20 & 15 & 21 & 9 & 85 & 10 \\
\hline 4 & NRRL NRS-815 & 51.8 & 21 & 21 & 14 & 5 & 13 & 70 \\
\hline 5 & NRRL NRS- $1206^{\mathrm{T}}$ & 46.5 & 20 & 18 & 10 & 7 & 14 & 17 \\
\hline 6 & NRRL NRS-1207 & 46.7 & 21 & 11 & 14 & 7 & 15 & 15 \\
\hline 7 & NRRL NRS-1208 & 46.4 & 29 & 24 & 24 & 17 & 14 & 15 \\
\hline 8 & NRRL NRS-863 ${ }^{\mathrm{T}}$ & 47.2 & 6 & 23 & 13 & 4 & 16 & 3 \\
\hline 9 & NRRL NRS-1210 & 46.8 & 20 & 23 & 30 & 27 & 14 & 16 \\
\hline 10 & NRRL NRS-910 & 47.1 & 0 & 15 & 9 & 0 & 11 & 0 \\
\hline 11 & NRRL NRS- $818^{\mathrm{T}}$ & 51.3 & 20 & 27 & 33 & 17 & 15 & 19 \\
\hline 12 & NRRL NRS-1029b & 51.3 & 15 & 11 & 10 & 5 & 11 & 12 \\
\hline 13 & HP926 & 50.4 & $\mathrm{NT}^{b}$ & 10 & 12 & NT & NT & NT \\
\hline 14 & NRRL NRS-948 & 51.5 & 12 & 10 & 11 & 5 & 10 & 10 \\
\hline 15 & NRRL NRS-1373 & 50.9 & 10 & 11 & 8 & 5 & 9 & 8 \\
\hline 16 & CCM 1613 & 51.4 & 16 & 12 & 15 & 37 & 11 & 11 \\
\hline 17 & NCFB 1133 & 51.4 & 34 & 24 & 35 & NT & 17 & 27 \\
\hline 18 & NCFB 1158 & 51.4 & 18 & 15 & 17 & NT & 14 & 16 \\
\hline 19 & NCFB 1165 & 51.4 & 16 & 14 & 16 & 45 & 10 & 20 \\
\hline 20 & S038 & 51.7 & 31 & 25 & 26 & NT & 19 & 26 \\
\hline 21 & S042 & 51.7 & 28 & 17 & 22 & NT & 15 & 22 \\
\hline 22 & S043 & 51.2 & 25 & 17 & 16 & 12 & 17 & 16 \\
\hline 23 & S044 & 51.6 & 28 & 20 & 18 & 12 & 18 & 15 \\
\hline 24 & S047 & 51.6 & 26 & 19 & 22 & 11 & 17 & 20 \\
\hline 25 & E15 & 51.7 & 24 & 19 & 16 & 11 & 13 & 16 \\
\hline 26 & E16 & 51.8 & 24 & 18 & 16 & 15 & 14 & 16 \\
\hline
\end{tabular}

${ }^{a}$ Reassociation values are the averages of two determinations. The maximum variation observed was $9 \%$.

${ }^{b} \mathrm{NT}$, not tested.

DNA relatedness showed that this strain was closely related genetically to the group 6 strains.

Cellular fatty acid and quinone compositions. The cellular fatty acid and quinone compositions of strains NRRL NRS$1206^{\mathrm{T}}$, NRRL NRS-1208, NRRL NRS-863 ${ }^{\mathrm{T}}$, NRRL NRS-910, NRRL NRS- $818^{\mathrm{T}}$, and NRRL NRS-948 were determined. Table 4 shows that all of these strains contained anteiso- $C_{15: 0}$ ( 32 to $66 \%$ of the total cellular fatty acids) and iso- $\mathrm{C}_{15: 0}$ ( 8 to $42 \%$ ). All strains contained menaquinone 7 (more than $90 \%$ of the total menaquinone).

Immunological and genetic analyses of cell wall proteins. Figure 1A shows the banding patterns of the electrophoretically treated whole-cell proteins of all of the strains belonging to groups 2 and 4 through 7 . The Western blot analysis revealed that the antiserum against HWP cross-reacted with a number of bands from all of the strains tested, confirming the presence of the characteristic S-layer proteins (Fig. 1B).

Figure 2 shows that the DNAs from the group 2 and 4 through 7 strains examined hybridized with the HpaI-BglII probe, indicating that these organisms contained DNA base sequences very similar to the sequence of the HWP gene of strain HPD31. These results demonstrated that the group 2 and 4 through 7 strains contained S-layer proteins that were immunologically and genetically similar to those found in members of the $B$. brevis group $(8,11)$.

Phenotypic characterization. The 22 group 5 through 7 strains examined formed peritrichous, motile, rod-shaped cells which were strictly aerobic and produced oval spores in swollen sporangia. Their colonies were flat, smooth, circular, and entire.

The members of these three groups had a number of characteristics in common. Positive reactions were observed for catalase activity, development of an alkaline $\mathrm{pH}$ in VogesProskauer broth, and acid production from fructose. Negative results were obtained for the oxidase test, the Voges-Proskauer reaction, the egg yolk reaction, hydrolysis of starch and urea, production of hydrogen sulfide and indole, utilization of propionate, DL-lactate, alginate, malonate, and tartrate, and acid production from L-arabinose, D-galactose, lactose, sucrose, D-xylose, trehalose, salicin, D-sorbitol, L-sorbose, Dmannose, melibiose, L-rhamnose, inositol, erythritol, and adonitol.

The differentiating characteristics of the three groups are shown in Table 5.

\section{DISCUSSION}

On the basis of DNA relatedness values, the groups formerly designated groups 2 and 4 by Nakamura (7) were identified as $B$. choshinensis and $B$. parabrevis, respectively. DNA relatedness values of less than $35 \%$ indicated that the group 5 through 7 strains and 15 ungrouped $B$. brevis-like strains (including strain HP926 belonging to group B of Takagi et al.) were not members of previously described $B$. brevis-like species. Intragroup DNA relatedness values of more than $70 \%$ and intergroup DNA relatedness values of less than $26 \%$ suggested strongly that groups 5 through 7 were genetically distinct taxa. High levels of DNA relatedness also indicated that the 13 ungrouped strains (strains 14 through 26 in Table 1) and group B strain HP926 were members of group 7 and that ungrouped strain NRRL NRS-910 was a member of group 6.

Table 6 shows that groups 5 through 7 could be distinguished 
TABLE 3. DNA relatedness values for $B$. brevis sensu lato strains

\begin{tabular}{|c|c|c|c|c|c|c|c|c|c|}
\hline \multicolumn{2}{|r|}{ Strain } & \multicolumn{8}{|c|}{$\%$ Reassociation with DNA from ${ }^{a}$ : } \\
\hline $\begin{array}{c}\text { Laboratory } \\
\text { no. }\end{array}$ & Designation & $\begin{array}{c}\text { NRRL } \\
\text { NRS-1206 }^{\mathrm{T}}\end{array}$ & $\begin{array}{c}\text { NRRL } \\
\text { NRS-1208 }\end{array}$ & $\begin{array}{c}\text { NRRL } \\
{\text { NRS- } 863^{\mathrm{T}}}\end{array}$ & $\begin{array}{c}\text { NRRL } \\
\text { NRS-1210 }\end{array}$ & $\begin{array}{c}\text { NRRL } \\
\text { NRS- } 818^{T}\end{array}$ & $\begin{array}{c}\text { NRRL } \\
\text { NRS-1029b }\end{array}$ & $\begin{array}{c}\text { NRRL } \\
\text { NRS-948 }\end{array}$ & HP926 \\
\hline 5 & NRRL NRS-1206 ${ }^{\mathrm{T}}$ & 100 & 100 & 0 & 0 & 9 & 9 & 1 & $\mathrm{NT}^{b}$ \\
\hline 6 & NRRL NRS-1207 & 96 & 100 & NT & 0 & 12 & 9 & 0 & 8 \\
\hline 7 & NRRL NRS- 1208 & 97 & 100 & 0 & 11 & 4 & 10 & 0 & NT \\
\hline 8 & NRRL NRS- $863^{\mathrm{T}}$ & 3 & NT & 100 & 86 & 0 & NT & NT & NT \\
\hline 9 & NRRL NRS-1210 & 5 & 9 & 79 & 100 & 9 & 10 & 5 & NT \\
\hline 10 & NRRL NRS-910 & 0 & NT & 87 & 94 & 0 & NT & NT & NT \\
\hline 11 & NRRL NRS $-818^{\mathrm{T}}$ & 4 & 2 & 0 & 0 & 100 & 100 & 92 & 73 \\
\hline 12 & NRRL NRS-1029b & 9 & 11 & 0 & 0 & 85 & 100 & 100 & 75 \\
\hline 13 & HP926 & 5 & 7 & 20 & 8 & 100 & 99 & 99 & 100 \\
\hline 14 & NRRL NRS-948 & 3 & 0 & NT & 0 & 93 & 100 & 100 & 77 \\
\hline 15 & NRRL NRS-1373 & 6 & 11 & N'T & 11 & 85 & 74 & 74 & 72 \\
\hline 16 & CCM 1613 & 3 & 0 & N'T & 1 & 99 & 100 & 81 & 71 \\
\hline 17 & NCFB 1133 & 4 & 21 & NT & 18 & 100 & 100 & 100 & 97 \\
\hline 18 & NCFB 1158 & 10 & NT & NT & 0 & 93 & 100 & 90 & 73 \\
\hline 19 & NCFB 1165 & 19 & 16 & NT & 11 & 100 & 100 & 79 & 79 \\
\hline 20 & S038 & 26 & 0 & NT & 15 & 100 & 100 & 98 & 73 \\
\hline 21 & S042 & 13 & 0 & NT & 5 & 100 & 100 & 85 & 89 \\
\hline 22 & S043 & 5 & 9 & NT & 3 & 100 & 100 & 76 & 89 \\
\hline 23 & S044 & 17 & 4 & NT & 1 & 100 & 100 & 90 & 100 \\
\hline 24 & S047 & 5 & 9 & NT & 6 & 100 & 100 & 93 & 89 \\
\hline 25 & E15 & 19 & 0 & NT & 0 & 92 & 100 & 76 & 81 \\
\hline 26 & E16 & 3 & 0 & NT & 0 & 89 & 100 & 100 & 75 \\
\hline
\end{tabular}

${ }^{a}$ Reassociation values are the averages of two determinations. The maximum variation observed was $9 \%$.

${ }^{b} \mathrm{NT}$, not tested.

phenotypically from each other and from B. brevis, B. agri, B. centrosporus, B. migulanus, B. choshinensis, and B. parabrevis. Differences in as few as 2 and as many as 11 characteristics distinguish groups 5 through 7 from the previously described species.

The results of previous studies $(6,7,11)$ and this study strongly suggested that groups 5 through 7 are genetically and phenotypically distinct taxa and merit recognition as separate species. We propose the name Bacillus reuszeri sp. nov. for group 5 (strains NRRL NRS-1206 ${ }^{\mathrm{T}}$, NRRL NRS-1207, and NRRL NRS-1208). The name Bacillus formosus sp. nov., nom. rev. is proposed for group 6 (strains NRRL NRS-863 ${ }^{\mathrm{T}}$, NRRL
NRS-910, and NRRL NRS-1210), and the name Bacillus borstelensis sp. nov., nom. rev. is proposed for group 7 (strains NRRL NRS-818 ${ }^{\mathrm{T}}$, NRRL NRS-1029b, HP926, NRRL NRS948, NRRL NRS-1373, CCM 1613, NCFB 1133, NCFB 1158, NCFB 1165, S038, S042, S043, S044, S047, E15, and E16). The revived names are used for the same taxa to which they were originally applied, in accordance with Rules $27,28 \mathrm{a}, 33 \mathrm{a}$, and $33 \mathrm{c}$ of the International Code of Nomenclature of Bacteria (4).

Takagi et al. (11) and Shida et al. (9) pointed out that the presence of immunologically and genetically related S-layer proteins is a taxonomic marker which suggests that the species $B$. brevis, B. agri, B. centrosporus, B. choshinensis, and $B$.

TABLE 4. Cellular fatty acid compositions of $B$. brevis sensu stricto, B. agri, B. centrosporus, B. choshinensis, B. parabrevis, and the ungrouped $B$. brevis-like organisms

\begin{tabular}{|c|c|c|c|c|c|c|c|c|c|c|c|}
\hline \multicolumn{2}{|r|}{ Strain } & \multicolumn{10}{|c|}{$\%$ of total cellular fatty acids: } \\
\hline \multirow[b]{2}{*}{ Laboratory no. } & \multirow[b]{2}{*}{ Designation } & \multicolumn{9}{|c|}{ Saturated acids } & \multirow{2}{*}{$\begin{array}{l}\text { Unsaturated } \\
\text { acids }\end{array}$} \\
\hline & & $\mathrm{C}_{14}$ & $\mathrm{C}_{15}$ & $\mathrm{C}_{16}$ & iso- $\mathrm{C}_{14}$ & iso- $\mathrm{C}_{15}$ & iso- $\mathrm{C}_{16}$ & iso- $\mathrm{C}_{17}$ & $\begin{array}{c}\text { anteiso- } \\
\mathrm{C}_{15}\end{array}$ & $\begin{array}{c}\text { anteiso- } \\
\mathrm{C}_{17}\end{array}$ & \\
\hline \multicolumn{12}{|l|}{ Group 5 strains } \\
\hline 5 & NRRL NRS- $1206^{\mathrm{T}}$ & 1.0 & 0 & 3.3 & 1.3 & 8.9 & 3.3 & 1.1 & 64.5 & 5.1 & 1.8 \\
\hline 6 & NRRL NRS-1207 & 0.6 & 0 & 2.0 & 1.8 & 7.8 & 3.7 & 0.9 & 65.7 & 4.7 & 3.0 \\
\hline \multicolumn{12}{|c|}{ Group 6 strains } \\
\hline 8 & NRRL NRS-863 ${ }^{\mathrm{T}}$ & 0 & 0.2 & 1.9 & 0.2 & 24.4 & 1.8 & 8.5 & 43.6 & 4.4 & 14.4 \\
\hline 10 & NRRL NRS-910 & 0 & 0 & 2.1 & 0.5 & 14.7 & 1.8 & 5.5 & 48.0 & 6.6 & 9.7 \\
\hline \multicolumn{12}{|l|}{ Group 7 strains } \\
\hline 11 & NRRL NRS $-818^{\mathrm{T}}$ & 0.4 & 0.2 & 0.8 & 0.8 & 41.9 & 1.7 & 4.3 & 32.0 & 2.7 & 11.9 \\
\hline 14 & NRRL NRS-948 & 0.3 & 0.3 & 0.8 & 0.8 & 39.1 & 1.4 & 4.9 & 34.6 & 3.2 & 9.1 \\
\hline \multicolumn{12}{|l|}{ Type strains } \\
\hline 27 & B. brevis $\mathrm{JCM} 2503^{\mathrm{T}}$ & 0.4 & 0.7 & 2.7 & 0.6 & 17.6 & 3.5 & 5.3 & 54.4 & 9.6 & 4.2 \\
\hline 28 & B. agri NRRL NRS- $1219^{\mathrm{T}}$ & 0.6 & 0.4 & 2.5 & 0.6 & 41.0 & 2.6 & 4.4 & 40.4 & 4.2 & 1.9 \\
\hline 29 & B. centrosporus NRRL NRS- $664^{\mathrm{T}}$ & 0.7 & 0.3 & 1.8 & 1.3 & 22.5 & 2.6 & 1.9 & 62.4 & 3.8 & 0.9 \\
\hline 31 & B. choshinensis HPD52 $^{\mathrm{T}}$ & 1.4 & 0.8 & 3.5 & 1.3 & 11.7 & 2.4 & 0.9 & 71.7 & 4.1 & 1.2 \\
\hline 33 & B. parabrevis IFO $12334^{\mathrm{T}}$ & 0.6 & 0.6 & 1.7 & 0.9 & 32.3 & 1.5 & 2.9 & 53.5 & 3.9 & 1.2 \\
\hline
\end{tabular}


(A)

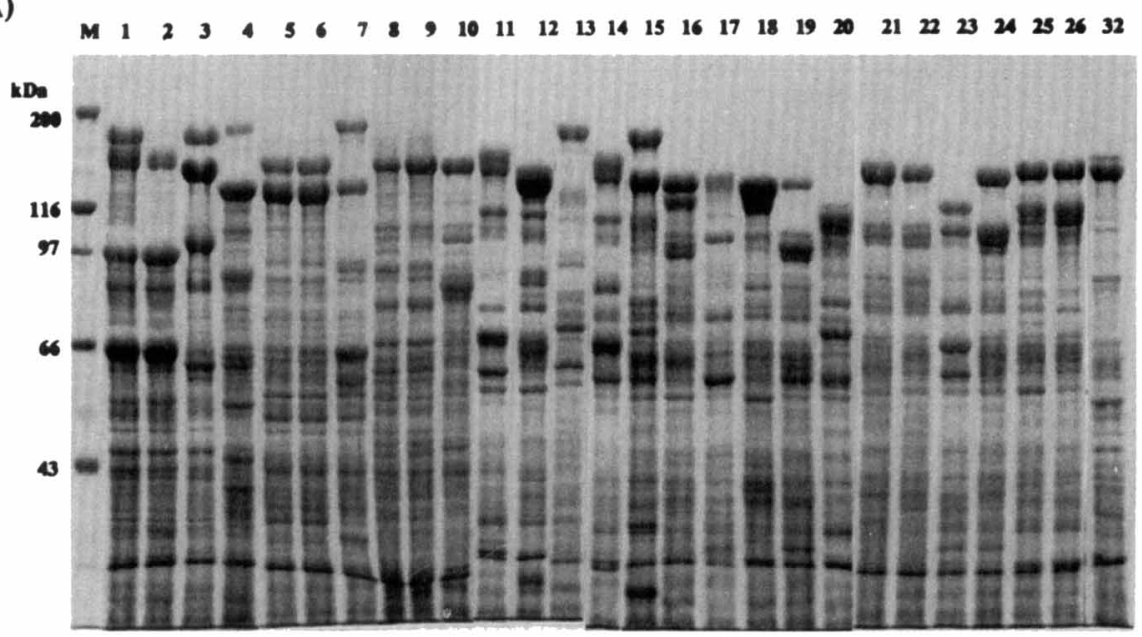

(B)

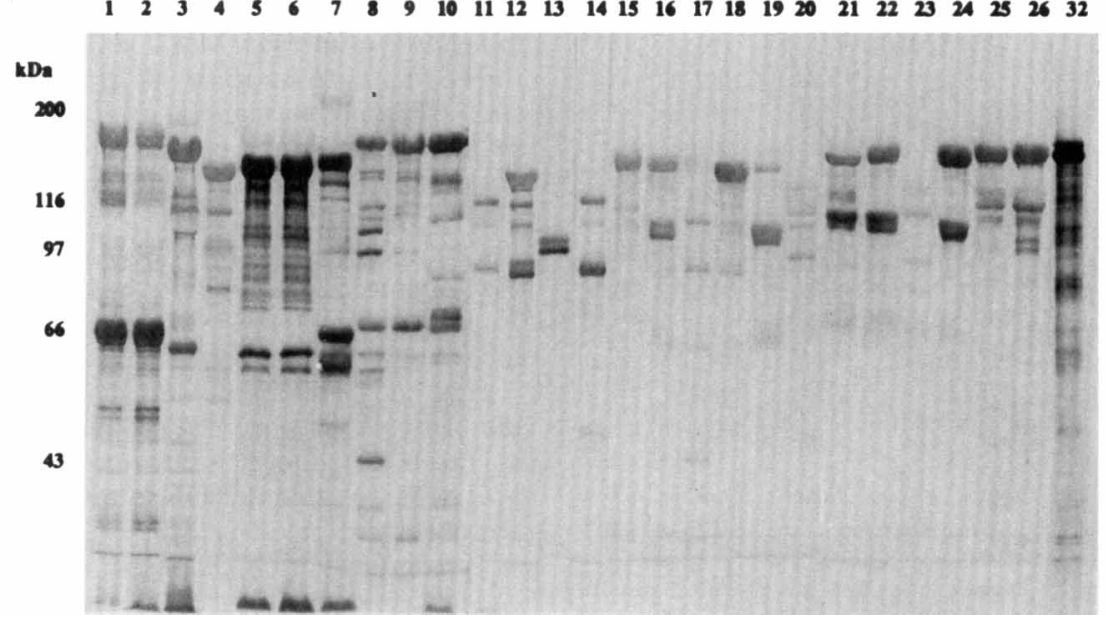

FIG. 1. Detection of S-layer proteins of strains formerly assigned to B. brevis. (A) Sodium dodecyl sulfate-7.5\% polyacrylamide Coomassie blue-stained gel of whole-cell proteins. (B) Western blot analysis. Proteins on a sodium dodecyl sulfate- $7.5 \%$ polyacrylamide gel were transferred electrophoretically to nitrocellulose sheets. Immunoreactive protein bands containing antiserum against the S-layer protein (protein HWP) of B. choshinensis HPD31 were detected with an immunostaining HRP kit (Konica Co., Tokyo, Japan). The lane numbers correspond to the strain numbers in Table 1. Lane $M$ contained marker proteins.

parabrevis are closely related taxonomically. This group of organisms may be distinguished by the $B$. brevis group type of $S$ layer (11). A different immunologically and genetically distinct $\mathrm{S}$ layer is found in the cell walls of Bacillus aneurino- lyticus and B. migulanus (9). These species may informally be designated the $B$. aneurinolyticus group. The data in this study revealed the presence of $S$-layer proteins in the three new species that were immunologically and genetically related to

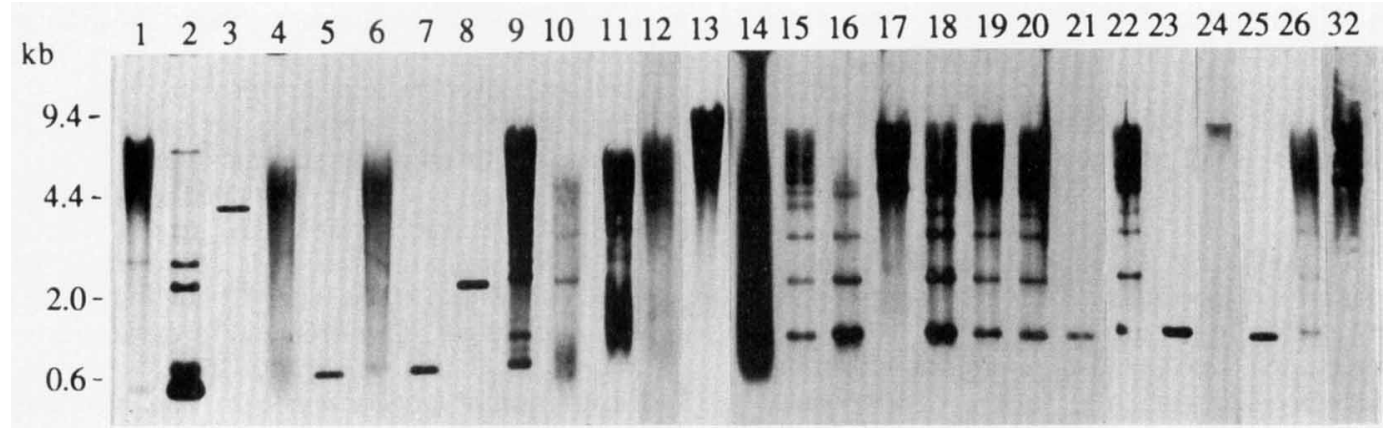

FIG. 2. Detection of homologous regions of the S-layer protein genes of strains formerly assigned to $B$. brevis by Southern blot analysis. The probe used for hybridization was the 1.0-kb HpaI-BglII fragment containing the HWP gene of $B$. choshinensis HPD31 (1, 11). Chromosomal DNAs were completely digested with EcoRI. Hybridization was detected with the enhanced chemiluminescence gene detection system (Amersham International plc) by using the manufacturer's protocol. The lane numbers correspond to the strain numbers in Table 1. 
TABLE 5. Distinctive phenotypic characteristics of B. reuszeri, $B$. formosus, and B. borstelensis

\begin{tabular}{|c|c|c|c|}
\hline Characteristic & $\begin{array}{l}\text { B. reuszeri } \\
\text { (group 5) } \\
(n=3)^{a}\end{array}$ & $\begin{array}{l}\text { B. formosus } \\
\text { (group 6) } \\
(n=3)\end{array}$ & $\begin{array}{l}\text { B. borstelensis } \\
\quad(\text { group 7) } \\
(n=16)\end{array}$ \\
\hline Nitrate reduction & $0^{b}$ & 100 & 100 \\
\hline \multicolumn{4}{|l|}{ Hydrolysis of: } \\
\hline Casein & 0 & 100 & 100 \\
\hline Gelatin & 0 & 100 & 100 \\
\hline DNA & 0 & 100 & 100 \\
\hline Decomposition of tyrosine & 100 & 0 & 100 \\
\hline \multicolumn{4}{|l|}{ Growth at: } \\
\hline pH 5.5 or 5.6 & 100 & 0 & 0 \\
\hline $15^{\circ} \mathrm{C}$ & 100 & 100 & 0 \\
\hline $50^{\circ} \mathrm{C}$ & 0 & 0 & 100 \\
\hline \multicolumn{4}{|l|}{ Growth in the presence of: } \\
\hline $2 \% \mathrm{NaCl}$ & 100 & 0 & 0 \\
\hline $3 \% \mathrm{NaCl}$ & 100 & 0 & 0 \\
\hline $0.001 \%$ lysozyme & 0 & 100 & 0 \\
\hline \multicolumn{4}{|l|}{ Utilization of: } \\
\hline Citrate & 0 & 100 & 0 \\
\hline Propionate & 0 & 0 & 0 \\
\hline Acetate & 0 & 100 & 0 \\
\hline Fumarate & 0 & 100 & 0 \\
\hline L-Malate & 0 & 100 & 0 \\
\hline Succinate & 0 & 100 & 0 \\
\hline L-Glutamate & 0 & 100 & 0 \\
\hline L-Aspartate & 0 & 66 & 0 \\
\hline Gluconate & 0 & 66 & 0 \\
\hline$\alpha$-Ketoglutarate & 0 & 100 & 0 \\
\hline \multicolumn{4}{|l|}{ Acid production from: } \\
\hline D-Glucose & 100 & 100 & 13 \\
\hline Maltose & 100 & 100 & 13 \\
\hline Glycerol & 100 & 100 & 0 \\
\hline D-Mannitol & 100 & 0 & 0 \\
\hline D-Cellobiose & 100 & 0 & 0 \\
\hline D-Ribose & 100 & 0 & 13 \\
\hline Raffinose & 100 & 0 & 0 \\
\hline
\end{tabular}

${ }^{a} n$, number of strains examined.

${ }^{b}$ Values are the percentages of strains that exhibit positive reactions. In addition, the $\mathrm{G}+\mathrm{C}$ contents of $B$. reuszeri, $B$. formosus, and $B$. borstelensis are 46 to 47,47 , and 50 to $52 \mathrm{~mol} \%$, respectively.

the S-layer proteins found in members of the B. brevis group. This observation allowed us to place the three new species in the $B$. brevis group.

Description of Bacillus reuszeri sp. nov. Bacillus reuszeri (reus.ze'ri. M. L. adj. reuszeri, of Reuszer, referring to H. W. Reuszer, the person who isolated the organism). Cells are rods that are 0.5 to 0.9 by 2.0 to $5.0 \mu \mathrm{m}$. Gram positive. Motile with peritrichous flagella. Ellipsoidal spores are formed in swollen sporangia. Colonies are flat, smooth, circular, and entire. Soluble pigment is not produced on nutrient agar.

Strictly aerobic.

Catalase positive and oxidase negative.

Acetylmethylcarbinol is not produced (as determined by the Voges-Proskauer test). The $\mathrm{pH}$ in Voges-Proskauer broth is higher than 7.0.

Hydrogen sulfide, indole, and lecithinase (as determined by the egg yolk test) are not produced.

Nitrate is not reduced to nitrite.

Casein, gelatin, starch, DNA, and urea are not hydrolyzed. Tyrosine is decomposed.

Citrate, propionate, acetate, fumarate, L-malate, DL-lactate, succinate, L-glutamate, L-aspartate, alginate, gluconate, $\alpha$-ketoglutarate, malonate, and tartrate are not utilized.

Growth occurs at pHs 5.5 and 5.6 and in the presence of $2 \%$
$\mathrm{NaCl}$. Growth is inhibited by $3 \% \mathrm{NaCl}$, by $0.001 \%$ lysozyme, and at $50^{\circ} \mathrm{C}$.

The optimum growth temperature is $30^{\circ} \mathrm{C}$, the maximum growth temperature is $45^{\circ} \mathrm{C}$, and the minimum growth temperature is $10^{\circ} \mathrm{C}$ (lowest temperature tested).

Acid but no gas is produced from D-glucose, D-fructose, maltose, glycerol, D-mannitol, D-cellobiose, D-ribose, and raffinose. Neither acid nor gas is produced from L-arabinose, D-galactose, lactose, sucrose, D-xylose, trehalose, salicin, Dsorbitol, L-sorbose, D-mannose, melibiose, L-rhamnose, inositol, erythritol, and adonitol.

Specific S-layer proteins are present.

The major fatty acid is anteiso- $\mathrm{C}_{15: 0}$ acid; the major quinone is menaquinone 7.

The $\mathrm{G}+\mathrm{C}$ content ranges from 46.4 to $46.7 \mathrm{~mol} \%$; the $\mathrm{G}+\mathrm{C}$ content of the type strain is $46.5 \mathrm{~mol} \%$. The type strain is NRRL NRS-1206, which was isolated from soil. The type strain has been deposited in the Japan Collection of Microorganisms, Saitama, Japan, as JCM 9170 and in the Institute for Fermentation, Osaka, Japan, as IFO 15719.

Description of Bacillus formosus sp. nov., nom. rev. Bacillus formosus (for.mo'sus. M. L. adj. formosus, beautiful). Cells are rods that are 0.5 to 0.9 by 2.0 to $5.0 \mu \mathrm{m}$. Gram positive. Motile with peritrichous flagella. Ellipsoidal spores are formed in swollen sporangia. Colonies are flat, smooth, circular, and entire. Soluble pigment is not produced on nutrient agar.

Strictly aerobic.

Catalase positive and oxidase negative.

Acetylmethylcarbinol is not produced (as determined by the Voges-Proskauer test). The $\mathrm{pH}$ in Voges-Proskauer broth is higher than 7.0.

Hydrogen sulfide, indole, and lecithinase (as determined by the egg yolk test) are not produced.

Nitrate is reduced to nitrite.

Casein, gelatin, and DNA are hydrolyzed. Starch and urea are not hydrolyzed.

Tyrosine is not decomposed.

Citrate, acetate, fumarate, L-malate, succinate, L-glutamate, and $\alpha$-ketoglutarate are utilized. L-Aspartate and gluconate are utilized by some strains. Propionate, DL-lactate, alginate, and tartrate are not utilized.

Growth occurs at pHs 5.5 and 5.6 and in the presence of $0.001 \%$ lysozyme. Growth is inhibited by $2 \% \mathrm{NaCl}$ and at $50^{\circ} \mathrm{C}$.

The optimum growth temperature is $30^{\circ} \mathrm{C}$, the maximum growth temperature is $45^{\circ} \mathrm{C}$, and the minimum growth temperature is $10^{\circ} \mathrm{C}$ (lowest temperature tested).

Acid but no gas is produced from D-glucose, D-fructose, maltose, and glycerol. Neither acid nor gas is produced from L-arabinose, D-galactose, lactose, sucrose, D-xylose, trehalose, D-mannitol, D-cellobiose, D-ribose, salicin, D-sorbitol, D-mannose, melibiose, L-rhamnose, raffinose, inositol, erythritol, and adonitol.

Specific S-layer proteins are present.

The major cellular fatty acids are anteiso- $C_{15: 0}$ and iso- $C_{15: 0}$ acids; the major quinone is menaquinone 7 .

The $\mathrm{G}+\mathrm{C}$ content ranges from 46.8 to $47.2 \mathrm{~mol} \%$; the $\mathrm{G}+\mathrm{C}$ content of the type strain is $47.2 \mathrm{~mol} \%$. The type strain is NRRL NRS-863, which was isolated from soil. The type strain has been deposited in the Japan Collection of Microorganisms, Saitama, Japan, as JCM 9169 and in the Institute for Fermentation, Osaka, Japan, as IFO 15716.

Description of Bacillus borstelensis sp. nov., nom. rev. Bacillus borstelensis (bor.stel.en'sis. M. L. adj. borstelensis, referring to Borstel, the German city where the organism was isolated). Cells are rods that are 0.5 to 0.9 by 2.0 to $5.0 \mu \mathrm{m}$. Gram positive. Motile with peritrichous flagella. Ellipsoidal spores 
TABLE 6. Differentiation of the species belonging to the B. brevis group and B. migulanus

\begin{tabular}{|c|c|c|c|c|c|c|c|c|c|}
\hline Characteristic & B. reuszeri ${ }^{a}$ & B. formosus ${ }^{a}$ & B. borstelensis ${ }^{a}$ & B. brevis $^{b, c}$ & B. $a g r^{d}$ & B. centrosporus ${ }^{d}$ & B. migulanus ${ }^{e}$ & B. choshinensis ${ }^{b, d}$ & B. parabrevis ${ }^{b}$ \\
\hline Nitrate reduction & $-f$ & + & + & $\mathrm{v}$ & - & $\mathrm{v}$ & + & - & + \\
\hline Oxidase & - & - & - & $\mathrm{v}$ & - & - & $\mathrm{v}$ & $\mathrm{v}$ & $\mathrm{v}$ \\
\hline \multicolumn{10}{|l|}{ Hydrolysis of: } \\
\hline Casein & - & + & + & + & + & - & - & - & + \\
\hline Gelatin & - & + & + & + & NT & NT & - & - & + \\
\hline DNA & - & + & + & + & NT & NT & + & - & + \\
\hline $\begin{array}{l}\text { Decomposition of } \\
\text { tyrosine }\end{array}$ & + & - & + & NT & + & + & + & - & NT \\
\hline \multicolumn{10}{|l|}{ Growth at: } \\
\hline pH 5.5 or 5.6 & + & - & - & - & + & - & + & - & $\mathrm{v}$ \\
\hline $15^{\circ} \mathrm{C}$ & + & + & - & $\mathrm{v}$ & + & + & - & + & $\mathrm{v}$ \\
\hline $50^{\circ} \mathrm{C}$ & - & - & + & - & - & - & + & - & $\mathrm{v}$ \\
\hline \multicolumn{10}{|l|}{$\begin{array}{l}\text { Growth in the } \\
\text { presence of: }\end{array}$} \\
\hline $2 \% \mathrm{NaCl}$ & + & - & - & $\mathrm{v}$ & NT & NT & + & - & $\mathrm{v}$ \\
\hline $3 \% \mathrm{NaCl}$ & + & - & - & NT & - & - & NT & - & NT \\
\hline $0.001 \%$ lysozyme & - & + & - & NT & - & - & + & - & NT \\
\hline Egg yolk reaction & - & - & - & NT & - & - & + & - & NT \\
\hline $\begin{array}{l}\text { Utilization of citrate } \\
\text { Acid produced from: }\end{array}$ & - & + & - & $\mathrm{v}$ & - & $\mathrm{v}$ & - & - & $\mathrm{v}$ \\
\hline D-Glucose & + & + & $\mathrm{v}$ & $\mathrm{v}$ & + & + & - & + & + \\
\hline D-Fructose & + & + & + & $\mathrm{v}$ & + & - & $\mathrm{v}$ & $\mathrm{v}$ & - \\
\hline Maltose & + & + & $\mathrm{v}$ & $\mathrm{v}$ & + & + & - & $\mathrm{v}$ & $\mathrm{v}$ \\
\hline Sucrose & - & - & - & $\mathrm{v}$ & + & + & - & $\mathrm{v}$ & $\mathrm{v}$ \\
\hline Trehalose & - & - & - & $\mathrm{v}$ & + & + & - & $\mathrm{v}$ & + \\
\hline D-Mannitol & + & - & - & + & + & + & - & $\mathrm{v}$ & + \\
\hline $\begin{array}{l}\text { Major cellular fatty } \\
\operatorname{acid}(s)\end{array}$ & $\begin{array}{l}\text { anteiso- } \\
\mathrm{C}_{15: 0}\end{array}$ & $\begin{array}{l}\text { iso- } \mathrm{C}_{15: 0} \\
\text { anteiso- } \mathrm{C}_{15: 0}\end{array}$ & $\begin{array}{c}\text { iso- } \mathrm{C}_{15: 0} \\
\text { anteiso- } \mathrm{C}_{15: 0}\end{array}$ & $\begin{array}{l}\text { iso- } \mathrm{C}_{15: 0} \\
\text { anteiso- } \mathrm{C}_{15: 0}\end{array}$ & $\begin{array}{l}\text { iso- } \mathrm{C}_{15: 0} \\
\text { anteiso- } \mathrm{C}_{15: 0}\end{array}$ & $\begin{array}{l}\text { iso- } \mathrm{C}_{15: 0} \\
\text { anteiso- } \mathrm{C}_{15: 0}\end{array}$ & $\begin{array}{c}\text { iso- } \mathrm{C}_{15: 0} \\
\mathrm{C}_{16: 0}, \text { iso- } \mathrm{C}_{16: 0}\end{array}$ & $\begin{array}{l}\text { iso- } \mathrm{C}_{15: 0} \\
\text { anteiso- } \mathrm{C}_{15: 0}\end{array}$ & $\begin{array}{l}\text { iso- } \mathrm{C}_{15: 0} \\
\text { anteiso- } \mathrm{C}_{15: 0}\end{array}$ \\
\hline $\begin{array}{l}\mathrm{G}+\mathrm{C} \text { content } \\
(\mathrm{mol} \%)\end{array}$ & $46-47$ & 47 & $50-52$ & $46-48$ & $52-54$ & $49-50$ & $42-43$ & $48-51$ & $51-53$ \\
\hline
\end{tabular}

${ }^{a}$ Data obtained in this study.

${ }^{b}$ Data from reference 11 .

${ }^{c}$ Data from reference 6.

d Data from reference 7

${ }^{e}$ Data from reference 9 .

$f_{-}$, negative reaction; + , positive reaction; $\mathrm{v}$, variable reaction; NT, not tested.

are formed in swollen sporangia. Colonies are flat, smooth, circular, and entire. NRRL NRS-948 produces a soluble brown-red pigment(s) on nutrient agar.

Strictly aerobic.

Catalase positive and oxidase negative.

Acetylmethylcarbinol is not produced (as determined by the Voges-Proskauer test). $\mathrm{pH}$ values higher than 7.0 are measured in Voges-Proskauer broth.

Hydrogen sulfide, indole, and lecithinase (as determined by the egg yolk test) are not produced.

Nitrate is reduced to nitrite.

Casein, gelatin, and DNA are hydrolyzed. Starch and urea are not hydrolyzed.

Tyrosine is decomposed.

Citrate, propionate, acetate, fumarate, L-malate, DL-lactate, succinate, L-glutamate, L-aspartate, alginate, gluconate, $\alpha$-ketoglutarate, malonate, and tartrate are not utilized.

Growth occurs at pH 5.5 and 5.6. Growth is inhibited by $2 \%$ $\mathrm{NaCl}$, by $0.001 \%$ lysozyme, and at $55^{\circ} \mathrm{C}$.

The optimum growth temperature is $30^{\circ} \mathrm{C}$, the maximum growth temperature is $50^{\circ} \mathrm{C}$, and the minimum growth temperature is $20^{\circ} \mathrm{C}$ (lowest temperature tested).

Acid but no gas is produced from $D$-fructose. Variable reactions are observed with $\mathrm{D}$-glucose, maltose, and D-ribose. Neither acid nor gas is produced from L-arabinose, D-galactose, lactose, sucrose, D-xylose, trehalose, glycerol, D-mannitol, L-sorbose, D-mannose, melibiose, L-rhamnose, raffinose, inositol, erythritol, and adonitol.
Specific S-layer proteins are present.

The major cellular fatty acids are iso- $\mathrm{C}_{15: 0}$ and anteiso- $\mathrm{C}_{15: 0}$ acids; the major quinone is menaquinone 7 .

The $\mathrm{G}+\mathrm{C}$ content ranges from 50.4 to $51.8 \mathrm{~mol} \%$; the $\mathrm{G}+\mathrm{C}$ content of the type strain is $51.3 \mathrm{~mol} \%$. The type strain is NRRL NRS-818, which was isolated from soil in Borstel, Germany. The type strain has been deposited in the Japan Collection of Microorganisms, Saitama, Japan, as JCM 9022 and in the Institute for Fermentation, Osaka, Japan, as IFO 15714.

\section{ACKNOWLEDGMENTS}

We thank Y. Sakaguchi for her able technical assistance and F. G. Priest of Heriot-Watt University and M. Abe of Yamaguchi University School of Medicine for supplying some of the cultures used in this study.

\section{REFERENCES}

1. Ebisu, S., A. Tsuboi, H. Takagi, Y. Naruse, H. Yamagata, N. Tsukagoshi, and S. Udaka. 1991. Conserved structure of cell wall protein genes among protein-producing Bacillus brevis strains. J. Bacteriol. 172:1312-1320.

2. Ezaki, T., Y. Hashimoto, and E. Yabuuchi. 1989. Fluorometric deoxyribonucleic acid-deoxyribonucleic acid hybridization in microdilution wells as an alternative to membrane filter hybridization in which radioisotopes are used to determine relatedness among bacterial strains. Int. J. Syst. Bacteriol. 39: 224-229.

3. Komagata, K., and K. Suzuki. 1987. Lipid and cell-wall analysis in bacterial systematics. Methods Microbiol. 19:161-207.

4. Lapage, S. P., P. H. A. Sneath, E. F. Lessel, V. B. D. Skerman, H. P. R. Seeliger, and W. A. Clark (ed.). 1990. International code of nomenclature of 
bacteria. 1990 revision. American Society for Microbiology, Washington, D.C.

5. Moore, W. E. C., and L. V. H. Moore. 1989. Index of the bacterial and yeast nomenclatural changes. American Society for Microbiology, Washington, D.C.

6. Nakamura, L. K. 1991 . Bacillus brevis Migula 1900 taxonomy: reassociation and base composition of DNA. Int. J. Syst. Bacteriol. 41:510-515.

7. Nakamura, L. K. 1993. DNA relatedness of Bacillus brevis Migula 1900 strains and proposal of Bacillus agri sp. nov., nom. rev., and Bacillus centrosporus sp. nov., nom. rev. Int. J. Syst. Bacteriol. 43:20-25.

8. Shida, O., H. Takagi, K. Kadowaki, S. Udaka, and K. Komagata. 1994 Bacillus galactophilus is a later subjective synonym of Bacillus agri. Int. J. Syst. Bacteriol. 44:172-173.

9. Shida, O., H. Takagi, K. Kadowaki, H. Yano, M. Abe, S. Udaka, and K.
Komagata. 1994. Bacillus aneurinolyticus sp. nov., nom. rev. Int. J. Syst. Bacteriol. 44:143-150.

10. Skerman, V. B. D., V. McGowan, and P. H. A. Sneath (ed.). 1989. Approved lists of bacterial names, amended edition. American Society for Microbiology, Washington, D.C.

11. Takagi, H., O. Shida, K. Kadowaki, K. Komagata, and S. Udaka. 1993 Characterization of Bacillus brevis with descriptions of Bacillus migulanus $\mathrm{sp}$. nov., Bacillus choshinensis sp. nov., Bacillus parabrevis sp. nov., and Bacillus galactophilus sp. nov. Int. J. Syst. Bacteriol. 43:221-231.

12. Udaka, S. 1976. Screening for protein-producing bacteria. Agric. Biol. Chem. 40:523-528. 